\title{
Egzystencjalna rola choroby
}

\section{Wprowadzenie}

\begin{abstract}
W/spółczesna cywilizacja zachodnia jest nastawiona na promowanie hedoni$\bigvee$ zmu,w którym naczelne miejsce zajmują: dobre zdrowie, kult ciała, pociągający i piękny wygląd, doznawanie przyjemności i zadowolenie, konsumpcja, wygodne i szczęśliwe życie. Popularność zyskuje eudajmonizm i sybarytyzm. Człowiek chce wieść życie dostatnie, folgując wszelakim przyjemnościom. Tysiące reklam prezentowanych każdego dnia w środkach masowego przekazu mają mu pomóc w wyborze towarów i usług pozwalających osiągnąc stan radości z życia i pogodę ducha. Priorytetem staje się zatem tworzenie systemu społecznego, który zapewni obywatelom miłą i dostatnią egzystencję. Wydaje się, że współczesny człowiek zapomina, iż musi umrzeć.

W społeczeństwie, w którym głównymi wartościami stają się dobrobyt, używanie i przyjemne życie coraz mniej mówi się o chorobie i cierpieniu. Tematy te bywają dyskretnie pomijane przez środki masowego przekazu, by nie burzyć kreowanej wizji o nieograniczonych możliwościach ludzkości, pragnącej zapewnić sobie dostatnią przyszłość na ziemi. Iluzoryczne zapowiedzi zbudowania ziemskiego raju są jednak zakłócane przez chorobę, cierpienie i kres ludzkiej egzystencji. Dlatego też współczesny człowiek często postrzega chorobę, cierpienie i śmierć jako bezsensowne i niechciane zło, które burzy jego utopijną i hedonistyczną wizję świata ${ }^{1}$.
\end{abstract}

\footnotetext{
* Dr Marek Adam Motyka - Instytut Socjologii, Wydział Socjologiczno-Historyczny, Uniwersytet Rzeszowski, e-mail: mmotyka@ur.edu.pl, ORCID: 0000-0001-6967-0035.

** Dr hab. Witold Jedynak, prof. UR - Instytut Socjologii, Wydział Socjologiczno-Historyczny, Uniwersytet Rzeszowski, e-mail: vox321@interia.pl, ORCID: 0000-0002-7101-8537.

${ }^{1}$ Por. P. Mrzygłód, Etyczno-moralne postawy wobec cierpienia, nieuleczalnej choroby i śmierci człowieka - wświetle ustaleń antropologii filozoficznej, „Studia Teologiczne - Białystok - Drohiczyn - Łomża" 2016, nr 34(2), s. 62-65.
} 
W powszechnej opinii to zdrowie nadaje sens życiu i jest stanem, którego życzenie posiadania przywoływane jest niemal we wszystkich zaistniałych okazjach podczas składania powinszowań. Stanowi wartość, którą trudno podważyć racjonalnymi argumentami. Definicje ludowe określają zdrowie obfitością witalności fizycznej, a ludzi o takich dyspozycjach mianem „tryskających zdrowiem”. Dla firm ubezpieczeniowych osoba zdrowa to zdolna do pracy, z kolei dla personelu medycznego zdrowie jest brakiem ograniczeń i bólów, zarówno organicznych, jak i funkcjonalnych, zaś według Światowej Organizacji Zdrowia (WHO) to stan zupełnego dobrostanu fizycznego, psychicznego i społecznego w relacji jednostki z otoczeniem ${ }^{2}$. Choroby natomiast, zwłaszcza niespodziewane, przewlekłe, niosące cierpienie oraz powodujące rozpad ładu i spójności w dotychczasowej egzystencji, skłaniają niezmiennie do stawiania pytań o celowość cierpienia ${ }^{3}$. Człowiek w obliczu choroby i cierpienia stawia najważniejsze pytania dotyczące własnej egzystencji. Tajemnica jego losu ujawnia się zwłaszcza w obliczu śmierci. Człowieka dręczą nie tylko boleści i postępujący rozkład ciała, ale jeszcze bardziej lęk przed unicestwieniem na zawsze. Nie tylko wzdryga się on przed całkowitą zagładą i ostatecznym końcem swego istnienia, ale je odrzuca, buntując się przeciw śmierci ${ }^{4}$.

W ujęciu chrześcijańskim choroba jest postrzegana jako konsekwencja misterium iniquitatis (tajemnicy nieprawości). W Biblii dolegliwości zdrowotne zazwyczaj łączono z grzechem i śmiercią5. Ich występowanie tłumaczono jako ostrzeżenie przed pogrążaniem się człowieka w grzechu, a średniowieczni kaznodzieje wskazywali chorobę jako karę za życie niezgodne z przykazaniami zalecając wierzącym modlitwę i pokutę, jako antidotum mające ukoić doznawane cierpienia ${ }^{6}$.

Uznanie ciężkiej choroby jako kary za doczesne uczynki, to jeden z kulturowych wizerunków cierpienia nałożonego na daną osobę ${ }^{7}$. Jednak starotestamentowy opis cierpień niewinnego Hioba, bądź też choroby dotykające współczesnych ludzi uznanych za świętych (Jana Pawła II) i prawych (ks.

2 Por. M.Á. Monge. Zdrowie, ból i choroba, w: Etyka w medycynie. Ujęcie interdyscyplinarne, red. M.Á. Monge, Warszawa 2012, s. 184.

3 Por. W. Przygoda, Teologia cierpienia i choroby, „Śląskie Studia Historyczno-Teologiczne” 2000, nr 33, s. 258-359.

${ }^{4}$ Por. Sobór Watykański II, Konstytucja duszpasterska o Kościele w świecie współczesnym, w: Konstytucje, dekrety, deklaracje, wyd. 3, Poznań br, s. 549 (nr 18).

${ }_{5}$ Por. I.S. Ledwoń, Teologiczna interpretacja sensu cierpienia, w: Cierpienie, między sensem a bezsensem. Studium interdyscyplinarne, red. M. Kalinowski, I. Niewiadomska, L. Szot, LublinŁuck 2014, s. 11.

${ }^{6}$ Por. B. Žuromskaite, Choroba: kara czy wyzwolenie? Stosunek do choroby w epoce nowożytnej, wydanie internetowe: http://www.racjonalista.pl/kk.php/s,4771 [dostęp: 25.06.2018].

7 Por. S. Sontag, Choroba jako metafora. AIDS i jego metafory, Kraków 2016, s. 7-10. 
Jana Kaczkowskiego), stawiają egzystencjalne pytania i stanowią argumenty potwierdzające niezawinione doświadczanie bolesnych przypadłości. Skoro więc choroby niekoniecznie bywają karą za popełnione winy, pojawia się pytanie o sens, o użyteczność przeżywanych udręk ${ }^{8}$. Poszukiwanie sensu cierpienia ma niebagatelne znaczenie dla utrzymania w całości dezintegrowanych przez chorobę elementów składowych człowieka; już chorującej fizyczności z bezcennymi i wysoce pomocnymi w chorobie sferami: psychiczną, duchową, jak i społecznym wymiarem funkcjonowania cierpiącej jednostki.

Celem niniejszego artykułu, przygotowanego w odwołaniu do publikacji poruszających kwestie ludzkiego cierpienia, jest próba ukazania egzystencjalnej roli choroby. Autorzy podjęli próbę odpowiedzi na następujące pytania: czy choroba i powiązane $\mathrm{z}$ nią cierpienie wpływa na poszukiwanie i odnajdywanie sensu życia czy też wskazuje na bezsensowność ludzkiej egzystencji? Jakie postawy wobec choroby przyjmują ludzie wierzący, a jakie niewierzący? Czy doświadczanie choroby różnicuje ludzi pod względem postrzegania przez nich swojej egzystencji? Czy choroba i cierpienie mogą być uznawane jako wartość w ludzkiej egzystencji?

\section{Zróżnicowane ujęcia ludzkiej egzystencji: egzystencjalizm ateistyczny}

Odpowiedzi na wyartykułowane we wprowadzeniu pytania można poszukiwać u przedstawicieli egzystencjalizmu. Uważają oni, że człowiek został „wrzucony" w istnienie i znalazł się w świecie, ale nikt go wedle żadnej idei nie zrobił, „nic z góry własności jego nie przesądza, a jaki będzie, to zależy od tego, co z siebie zrobi, może być tym czy innym, wszystkim albo niczym" Istnienie człowieka jest „kruche”, przelotne, przypadkowe, otoczone nicością, wypełnione trwogą i narażone na zniszczenie. Cechą ludzkiej egzystencji, która nie ma oparcia poza sobą, jest troska o istnienie i jego obrona. Człowiek sam nadaje sens swojemu istnieniu, ciążącemu ku śmierci. Tworzy też własne wartości, bo nie ma obowiązujących praw moralnych bądź nakazów ${ }^{10}$.

Egzystencjalizm koncentruje się na ludzkim bycie doświadczanym przez jednostkę subiektywnie; „na zagadnieniach związanych z wolnością, samotnością i skończonością człowieka w świecie, problemach ujmowanych w kategoriach dramatyzmu ludzkiego istnienia"11.

\footnotetext{
${ }_{8}$ Por. I. Siudem, Konsekwencje represji cierpienia, w: Cierpienie, między sensem a bezsensem. Studium interdyscyplinarne, red. M. Kalinowski, I. Niewiadomska, L. Szot, Lublin-Łuck 2014, s. 170.

${ }^{9}$ W. Tatarkiewicz, Historia filozofii, t. 3: Filozofia XIX wieku i współczesna, Warszawa 1981, s. 348.

${ }_{10}$ Por. tamże, s. 354.

${ }^{11}$ D. Bajer, Egzystencjalizm jako filozofia podmiotu, „IDEA - Studia nad strukturą i rozwojem pojęć filozoficznych" 2011, nr 23, s. 116.
} 
Jak pisał Zdzisław J. Czarniecki: „główną ideą egzystencjalizmu jest przekonanie, że człowiek jako jedyny spośród wszystkich bytów wyłącznie sam ustawicznie tworzy się tym, kim jest, dokonując własnych wewnętrznych wyborów, w których wyraża się wolność jako właściwy atrybut człowieczeństwa"12. Stanowisko to jest charakterystyczne dla egzystencjalistów ateistycznych reprezentowanych m.in. przez Martina Heideggera i Jeana Paula Sartre’a, którzy propagowali filozofię nicości i beznadziejności.

Według M. Heideggera, u podstaw wszelkiego bytu leży nicość, będąca warunkiem ujawnienia się bytu jako takiego. Naczelnym uczuciem ludzkiej egzystencji jest trwoga odkrywająca nicość. Trwoga staje się naturalnym stosunkiem człowieka do istnienia, uczuciem wyrażającym niepokój o własną egzystencję ${ }^{13}$. Przed człowiekiem stoi śmierć, której nie da się uniknąć, bo człowiek jest bytowaniem ku śmierci. Czas jest miarą ludzkiego istnienia. Gdy człowiek sobie to uświadamia poznaje własną skończoność, odpowiedzialność, wolność i autentyczność ${ }^{14}$.

O znikomości i kruchości istnienia człowieka pisze również J.-P. Sartre. Według niego, człowiek jest pierwotnie nikim, dopiero później staje się czymś i będzie takim, jakim sam się uczyni. Bóg nie istnieje, dlatego człowiek zmaga się ze swoją samotnością w świecie, nie znajdując ani w sobie, ani poza sobą oparcia. Skoro nie ma Boga, człowiek jest sam. Zatem nikt nie ogranicza jego wolności. Wszystko jest dla niego dozwolone, nie ma bowiem wartości ani nakazów usprawiedliwiających ludzkie postępowanie. Wraz z przyjęciem faktu, że Bóg nie istnieje, znika możliwość odnalezienia wartości w świecie idei ${ }^{15}$. Przyjęcie uniwersalnego systemu niezmiennych wartości byłoby - według Sartre’a próbą unicestwienia wolności człowieka. Wszelka tęsknota za obiektywnym porządkiem moralnym jest zatem nieautentyczna i oznacza utratę wolności ${ }^{16}$.

\section{Egzystencjalizm teistyczny}

Odmienną koncepcję dotyczącą ludzkiego istnienia ukazują przedstawiciele teistycznego ujęcia egzystencjalizmu (m.in. Søren Kierkegaard, Karl Jaspers).

12 Z.J. Czarnecki, Słownik najważniejszych terminów filozoficznych, w: Świat, człowiek i wartości. Wybór tekstów filozoficznych dla szkół średnich, red. J. Cabaj, Z.J. Czarnecki, H. Jakuszko, J. Zdybel, Warszawa 1988, s. 352.

${ }_{13}$ Por. B. Markiewicz, Od Nietzschego do filozofii współczesnej. Wybór tekstów, Warszawa 1999, s. 106-107.

14 Por. R.H. Popkin, A. Stroll, Filozofia, Poznań 1994, s. 517-518.

15 Por. B. Markiewicz, Od Nietzschego do filozofii współczesnej, s. 158, 161-162.

16 Por. R. Scruton, Filozofia kontynentalna od Fichtego do Sartrea, w: Oksfordzka ilustrowana historia filozofii, red. A. Kenny, Poznań 2001, s. 272. 
Według nich, życie człowieka jest determinowane przez siły znacznie od niego potężniejsze, a nieskończoność nie tylko istnieje, ale przenika skończone ludzkie istnienie. S. Kierkegaard jest przekonany, że człowiek łączy w sobie skończoność i nieskończoność, czasowość i wieczność, konieczność i wolność. Istniejące w nim sprzeczności, przeciwności i konflikty, od których nie może się uwolnić, są powodem cierpienia. Życie człowieka rozwija się i staje się coraz inne. Istnienie z jego zmiennością i niepokojem jest nieustannym stawaniem się. Człowiek wyrywa się z istnienia, które jest przemijaniem i dąży do wieczności. Wprowadzenie Boga do życia człowieka wywołuje u niego lęk, grozę i męczarnię. Człowiek może zdecydować się na skończoność albo na wieczność, nie ma rozwiązania pośredniego. Pozostaje zatem rozdarty między dążeniem do nieskończoności a doświadczaniem własnego, skończonego istnienia. Jeśli opowie się za skończonością wybierze nicość, natomiast optując za wiecznością doświadczy męczarni, ponieważ lęka się i obawia nieskończoności. Zbliżenie się przemijającego człowieka do wiecznego Boga poniża człowieka i przekonuje go o własnej bezsilności. Nadto wywołuje u niego lęk i drżenie ${ }^{17}$. Kierkegaard uważa, iż w religii człowiek staje wobec tajemnicy absurdalności swojego istnienia. Akt wiary generuje skrajne uczucia: trwogę, zwątpienie, rozpacz. Uczucia te, zwłaszcza rozpacz, mogą doprowadzić do wiary lub do jej odrzucenia ${ }^{18}$.

O poszukiwaniu przez człowieka transcendencji pisze Karl Jaspers. Uważa on, że w sytuacjach granicznych takich jak np. walka, cierpienie, śmierć, człowiek staje przed wyborem pogrążenia się w rozpaczy i rezygnacji lub też oparcia się na wierze przez skierowanie się ku transcendencji. Otwierając się na transcendencję człowiek urzeczywistnia swoją egzystencję. Wtedy też zostaje skonfrontowany z własną nieograniczoną wolnością i może doświadczyć autentycznej egzystencji ${ }^{19}$. Egzystencja człowieka, mimo jej ograniczoności, wyraża się w poszukiwaniu transcendencji, w tym własnego sensu istnienia. Wskazywane przez Jaspersa szyfry transcendencji uobecniają człowiekowi transcendencję; są Jej odpowiedzią na wołanie egzystencji ${ }^{20}$.

Dla prekursora egzystencjalizmu B. Pascala - przekonanego, że troska i groza śmierci wypełnia istnienie - człowiek jest istotą rozdartą pomiędzy nieuchronną skończonością a pragnieniem nieskończoności, przy czym sama skończoność ludzkiego bytu jawi się jako absurdalna i bezsensowna. Poszuku-

\footnotetext{
17 Por. W. Tatarkiewicz, Historia filozofii, t. 3, s. 65-67.

18 Por. R. Scruton, Filozofia kontynentalna od Fichtego do Sartrea, s. 259.

19 Por. A. Mordka, Transcendencja i sposoby jej poszukiwania w filozofii Karla Jaspersa, „Nowa Krytyka" 1996, nr 7, s. 190-196.

20 Por. M. Żelazny, Pojęcie znaku egzystencji i szyfru transcendencji w filozofii Jaspersa (próba komentarza), „Humanistyka i Przyrodoznawstwo” 2011, nr 17, s. 59-60; A. Mordka, Transcendencja i sposoby jej poszukiwania, s. 197-202.
} 
jąc ratunku przed egzystencjalną rozpaczą związaną z owym nieuchronnym końcem istnienia człowiek poszukuje Boga, gdyż tylko świadomość jego istnienia uzasadnia porządek świata, życia, umierania i nadaje tymże ostateczny sens ${ }^{21}$. Postawa ta wyraźnie różni się od poglądów myślicieli ateistycznych, dla których wierzenia religijne stanowią akt tchórzostwa, lub - jak mawiał Albert Camus - są filozoficznym samobójstwem²2.

Zarówno egzystencjalizm jak i chrześcijaństwo są przekonane o znikomości, kruchości i przemijalności ludzkiego istnienia. Jednak chrześcijaństwo postrzega istnienie jako moment w wieczności, natomiast egzystencjalizm - w nicości. Dla obu życie doczesne jest ukierunkowane na śmierć. W przeciwieństwie do egzystencjalizmu chrześcijaństwo ukazuje perspektywę wieczności nadającą sens istnieniu, gdyż w człowieku nieskończoność przenika skończone istnienie ${ }^{23}$.

Jak wskazuje Alfred Längle, „człowiek jako całość jest określony jako punkt skrzyżowania trzech różnych rodzajów bytu. Człowiek jest cielesny, psychiczny i duchowy zarazem. Te trzy wymiary tworzą między sobą specyficzne zależności, tak że nie można powiedzieć, że człowiek jest ich sumą. Człowiek jest jednością, całością, wewnątrz której wzajemnie układają się ciało, psychika i duch”24. Fizyczność człowieka implikuje jego dążenia do zachowania zdrowia, regulując je przez potrzeby biologiczne: sen, posiłek, ruch, życie intymne. Istota psychiczna w człowieku dąży do doświadczania przyjemnych uczuć i wolności od wszelkich wewnętrznych napięć i rozterek. Duchowość natomiast warunkuje poszukiwanie sensu istnienia, wartości, wiary, sprawiedliwości, wolności ${ }^{25}$. Załamanie się choćby jednego z tych komponentów może wprowadzić istotne zmiany egzystencjalne naruszając równowagę niezbędną do prawidłowego funkcjonowania.

\section{Choroba w egzystencji człowieka}

Choroba towarzyszy człowiekowi od początku jego istnienia na ziemi. Jest ona przyczyną problemów egzystencjalnych, skraca bowiem życie, a nierzadko bezpośrednio prowadzi do śmierci. Ludzkość podejmuje wzmożony wysiłek $\mathrm{w}$ walce $\mathrm{z}$ chorobą. Jego efektem jest znaczne ograniczenie występowania

\footnotetext{
${ }^{21}$ Por. D. Bajer, Egzystencjalizm jako filozofia podmiotu, s. 118.

22 Por. R.C. Solomon, K.M. Higgins, Krótka historia filozofii, Wydawnictwo Prószyński i S-ka, Warszawa 1997, s. 319.

${ }^{23}$ Por. W. Tatarkiewicz, Historia filozofii, t. 3, s. 352.

24 A. Längle, Analiza egzystencjalna - poszukiwanie zgody na życie, „Psychoterapia” 2003, nr 2(125), s. 36.

25 Por. tamże, s. 37.
} 
zachorowań w populacji. Nie udaje się jednak zupełnie wyeliminować choroby, gdyż w miejsce wyleczalnych jej odmian pojawiają się nowe, groźne lub nawet zabójcze dla człowieka. Choroba implikuje cierpienie, które staje się nieuchronnym elementem egzystencji i nikt nie jest od niego wolny. Jednak sposób w jaki cierpienie jest doświadczane może być dla każdego odmienny i zależy od sensu, jaki człowiek jest w stanie mu nadaćc ${ }^{26}$.

Nowoczesne i ponowoczesne społeczeństwa, w których dominuje nastawienie na materializm praktyczny i konsumpcjonizm nie dostrzegają żadnego znaczenia bądź wartości cierpienia spowodowanego chorobą. Wręcz przeciwnie, uważają je za zło samo w sobie, które za wszelką cenę należy eliminować z życia człowieka. W takich uwarunkowaniach społecznych i kulturowych bardzo trudno jest przyjąć i znosić cierpienie, zwłaszcza, gdy pojawia się możliwość rozwiązania problemu przez doprowadzenie do śmierci cierpiącego w momencie uznanym za najwłaściwszy. Chory, odczuwając lęk, trwogę, a nawet rozpacz wywołaną intensywnym i przedłużającym się bólem jest wystawiony na ciężką próbę trwania w cierpieniu, a także na pokusę zakończenia swojej egzystencji. Jeżeli zatem brakuje mu motywacji religijnej, aby pozytywnie rozumieć i znosić tajemnicę cierpienia, może podjąć desperacką próbę spowodowania własnej, przedwczesnej śmierci. W decyzji takiej w imię źle pojętej litości mogą utwierdzać go najbliżsi oraz lekarze ${ }^{27}$.

Osoby negujące istnienie Boga i jego interwencję w ludzkie losy są przekonane, że cierpienie nie wnosi niczego dobrego w egzystencję człowieka, wręcz przeciwnie jest powodem nieszczęścia. W ich ocenie, człowiek chory powinien autonomicznie decydować o swoim nastawieniu do cierpienia, kierując się przede wszystkim stanem zaawansowania choroby i perspektywą jej dalszego przebiegu. Nikt nie może choremu nakazywać znoszenie cierpienia, jeśli jest ono uciążliwe. Człowiek chory sam ma kształtować swoją egzystencję. Przedstawiciel egzystencjalizmu ateistycznego Jean-Pierre Sartre pisał, że „człowiek jest tylko tym, czym siebie uczyni”"28. Wobec braku obecności Boga jako kreatora świata i zasad na nim panujących, człowiek jest sam zobligowany do dokonywania swoich wyborów, tworzenia wartości, które go określają. Jest wolny, lub raczej skazany na wolność. Sartre’owska wolność daje człowiekowi możliwość projektowania swojej rzeczywistości - siebie samego - przez dokonywanie wyborów. Zrzuca na niego całkowitą odpowiedzialność za funkcjonowanie, stwarza możliwość przyjęcia autonomicznego

\footnotetext{
26 Por. P. Cattaneo, Dlaczego Bóg dopuszcza cierpienie?, Kraków 2008, s. 10.

27 Por. Jan Paweł II, Encyklika Evangelium vitae, Wydawnictwo Pallottinum, Poznań 1995, s. 27 (nr 15).

28 J.-P. Sartre, Egzystencjalizm jest humanizmem, w: Materializm historyczny. Etyka, red. A. Ochocki, S. Sarnowski, Warszawa 1969, s. 120.
} 
stanowiska wobec świata, wolne bycie w świecie ${ }^{29}$, czyni odpowiedzialnym za podejmowane bądź odrzucane inicjatywy, zwłaszcza w sytuacjach dla niego kryzysowych. Szukanie pomocy w wymiarze pozamaterialnym staje się irracjonalne, ponieważ duchowość człowieka jest poza możliwością poznania za pomocą empirii, a tym samym sens cierpienia i śmierci są również trudne do doświadczalnego uchwycenia ${ }^{30}$.

Oddziaływanie choroby na człowieka, który z nią się zmaga jest różne i nieprzewidywalne. Dla ludzi wierzących choroba i związane z nią cierpienie jest najczęściej postrzegane jako wola Boża, z którą należy się pogodzić i z wiarą przyjąć. Chrześcijanin doświadczony cierpieniem z reguły przeżywa je w odniesieniu do Boga, wierząc, że ma ono odkupieńczą wartość wobec grzechów i jest partycypacją w cierpieniu Chrystusa, który zbawił świat ${ }^{31}$. Nie zawsze jednak osoba wierząca przyjmuje chorobę, bywa, że buntuje się przeciwko cierpieniu, jakiego doznaje, a jej wiara słabnie lub całkowicie zanika, stając się powodem negacji Boga ${ }^{32}$. Dla ludzi niewierzących choroba jest wydarzeniem losowym, które zazwyczaj interpretują jako konsekwencję naturalnych biologicznych lub psychicznych zaburzeń w organizmie. Choroba, zwłaszcza terminalna, staje się dla nich zdarzeniem dramatycznym, w którym nie dostrzegają żadnego sensu, wręcz przeciwnie, wydaje się im złym oraz absurdalnym zjawiskiem zagrażającym egzystencji i wywołującym lęk przed unicestwieniem.

Jednak niektórzy ludzie niewierzący w chorobie odkrywają sens, gdy jest ona dla nich powodem i okazją do refleksji, uznania własnej znikomości, konwersji i spotkania $\mathrm{z}$ transcendencją. Poszukiwanie, a następnie przyjęcie przez nich transcendencji wskazuje, że odrzucają oni sartre'owską koncepcję humanizmu, która otwierając przed człowiekiem miraż absolutnej wolności, równocześnie uznaje tragizm i bezsens jego istnienia. Nadto cierpiący sprzeciwiają się ateistycznemu egzystencjalizmowi, który, ukazując przerażającą samotność jednostki, odbiera wszelką nadzieję a jego finalnym momentem jest rozpacz ${ }^{33}$.

Zarówno dla wierzących jak i niewierzących cierpienie pozostaje traumatyczną tajemnicą wobec której są oni bezradni. Jest ono źródłem trwogi i udręki. Kiedy jednak chory pozbawiony obowiązków i skazany na bezczyn-

\footnotetext{
${ }_{29}$ Por. M. Lewicki, O Jeana Paula Sartre’a projekcie człowieka w sytuacji, „Zeszyty Naukowe Towarzystwa Doktorantów Uniwersytetu Jagiellońskiego. Nauki Humanistyczne” 2011, nr 3(2), 46-51.

30 Por. A. Bartoszek, Moralne aspekty „jakości życia” w opiece paliatywnej, „Śląskie Studia Historyczno-Teologiczne" 2002, nr 35, s. 328.

31 Por. W. Przygoda, Teologia cierpienia i choroby, s. 264-265.

32 Por. A. Olczyk, Posłannictwo Kościoła wobec chorych, „Studia Gdańskie” 2014, nr 35, s. 80.

33 Por. B. Drożdż, Alienacja w świetle egzystencjalizmu, „Perspectiva. Legnickie Studia Teologiczno-Historyczne" 2006, nr 5(1), s. 57.
} 
ność pozostaje w osamotnieniu, wówczas ma możliwość podjęcia pogłębionej refleksji nad swoją egzystencją. Choroba dla osoby poszukującej pomocy i oparcia w cierpieniu może stać się impulsem ukierunkowującym istnienie na transcendencję. Katechizm Kościoła katolickiego zwraca uwagę na doniosła rolę choroby w odnajdywaniu przez człowieka sensu swojej egzystencji: „Choroba może prowadzić do niepokoju, do zamknięcia się w sobie, czasem nawet do rozpaczy i buntu przeciw Bogu, ale może także być drogą do większej dojrzałości, może pomóc lepiej rozeznać w swoim życiu to, co nieistotne, aby zwrócić się ku temu, co istotne. Bardzo często choroba pobudza do szukania Boga i powrotu do Niego" 34 .

\section{Przyczyny deprecjacji roli cierpienia}

Przyczyną negowania wartości cierpienia jest liberalna koncepcja wolności prowadząca do głębokiego zniekształcenia życia społecznego. Społeczeństwo odrzucające Boga zatraca poczucie wartości ludzkiego istnienia. Życie ludzkie bez transcendencji staje się bezsensownym przemijaniem ukierunkowanym na zaspokojenie doczesnych, cielesnych potrzeb, pragnień i przyjemności czerpanych z życia fizycznego. Wartością jest zdrowie i przyjemne bytowanie. W społeczeństwach konsumpcyjnych, w których propaguje się indywidualizm, hedonizm i utylitaryzm, człowieka chorego i cierpiącego nierzadko traktuje się jako ciężar i problem dla państwa, chcącego unikać nieproduktywnych wydatków obciążających budżet. Chory, któremu daje się odczuć, że stanowi niepotrzebny dla rodziny i społeczeństwa ciężar, łatwiej popada w rozpacz, której konsekwencją jest utrata sensu dalszej egzystencji. Zsekularyzowane społeczeństwo odrzucając cierpienie jako bezużyteczne zło, którego zawsze należy unikać, odbiera choremu motywację do przyjęcia cierpienia i do przedłużania własnego istnienia. Gdy przezwyciężenie choroby i cierpienia okazuje się niemożliwe, człowiek skłonny jest uznać, że życie straciło dla niego wszelki sens i należy położyć mu kres. Jeśli ludzka egzystencja zostaje uznana za pozbawioną dalszego sensu z powodu bólu i wzmagającego się cierpienia, wtedy śmierć staje się „upragnionym wyzwoleniem” ${ }^{35}$. Człowiek nastawiając się nihilistyczne do cierpienia ukierunkowuje swoje istnienie na nicość i bezsensowność.

Według egzystencjalistów ateistycznych sam wybór stanowiska i przyjęcie odpowiednich dla jednostki wartości są jednak niewystarczające, bowiem - jak pisał J.-P. Sartre: „człowiek przede wszystkim będzie tym, co stanowi

${ }^{34}$ Katechizm Kościoła Katolickiego, Poznań 1994, s. 356 (nr 1501).

35 Jan Paweł II, Encyklika Evangelium vitae, s. 36-43 (nr 20-23). 
realizację jego woli"36. Realizacja natomiast może odbywać się tylko poprzez działanie; czyn, który potwierdza i określa ową uznawaną wartość. Oczekiwanie jednak, że samo przyjęcie danego stanowiska będzie determinowało realizację woli jest według J.-P. Sartre’a błędem ${ }^{37}$, co ponadto jest spójne z racjonalnym myśleniem: jeżeli jednostka świadoma rozwijającej się choroby uzna zdrowie za wartość, to samo przyjęcie takiego stanowiska nie doprowadzi do wyzdrowienia, a raczej podjęte przez nią działania - wizyta u lekarza, przyjmowanie medykamentów, wprowadzenie zmian w stylu życia, etc. Wolność w tym ujęciu oznacza wspomnianą wcześniej odpowiedzialność za swoją sytuację; „skazuje” na odkrywanie i odnajdywanie siebie jako człowieka, co jednak może stanowić niebagatelne wyzwanie. Mikołaj Lewicki odwołując się do sartre’owskiego ujęcia wolności formułuje kwestie istotne dla niniejszych rozważań: „czy w dramatycznych momentach trwania egzystencji nie zawiodę, czy trudna sytuacja będzie dla mnie raczej pozorem, w którym odnajdę się jako masochista bądź od którego będę uciekał, a może będzie motywem do walki? Czy w końcu, cierpiąc, będę chciał cierpieć, czy też będę robił wszystko, co w mojej mocy, by unicestwić źródło cierpienia" ${ }^{38}$.

\section{Choroba jako źródło przemian}

Podczas choroby, zwłaszcza ciężkiej, człowiek doświadcza bezsilności, ograniczeń i świadomości końca, bowiem każde cierpienie może się łączyć z przewidywaniem śmierci. Wszelkie cierpienia związane z chorobami bądź starzeniem się mogą stać się źródłem niepokoju i wywoływać alienację. Jednak, jak zauważają L. Kazimierczak i P. Prüfer stanowią one rzeczywistość, poprzez którą człowiek zwraca się ku temu co dla niego istotne i wartościowe ${ }^{39}$. Max Scheler uważa, że wszelkie rodzaje doznawanych cierpień są stanami, „w których jakieś dobro niższego porządku zostaje poświęcone dla dobra wyższego porządku"40. Według Schelera, cierpienie jest koniecznym elementem egzystencji, gdyż ma charakter twórczy. Pozwala ono powstawać życiu i się rozwijać. W cierpieniu, „jakaś część ponosi ofiarę na rzecz rozwoju całości" ${ }^{41}$. Zdaniem Józefa Tarnawy cierpienie odsłania prawdziwe oblicze człowieka odrzucając przy tym wszystkie dotychczasowe iluzje, pozory, maski. Podczas cierpienia

\footnotetext{
36 J.-P. Sartre, Egzystencjalizm jest humanizmem, s. 120.

37 Por. tamże, s. 120-124.

38 M. Lewicki, O Jeana Paula Sartre’a projekcie człowieka w sytuacji, s. 55.

39 Por. L. Kazimierczak, P. Prüfer, Potrzeba istnienia hospicjum w parafii, s. 40-49.

${ }^{40}$ M. Scheler, Cierpienie, śmierć, dalsze życie, Wydawnictwo Naukowe PWN, Warszawa 1994, s. 13.

${ }^{41}$ K. Duda, Fenomenologia cierpienia. Zarys problematyki, w: Ból i cierpienie, red. G. MakiełłoJarża, Wydawnictwo Krakowska Akademia im. Andrzeja Frycza Modrzewskiego, Kraków 2011, s. 15.
} 
osoba chora wyraża swoją osobowość, ale przede wszystkim w pełni uczy się nowych wartości: opanowania, wytrwałości, cierpliwości, wrażliwości i otwartości na sprawy innych, jak również dokonuje radykalnych zmian w dotychczasowym systemie wartości, bowiem te wartości, które dotychczas były ważne mogą okazać się nieistotne w stanie choroby ${ }^{42}$.

Poszukując odpowiedzi na pytania o sens choroby warto odwołać się do stanowiska Blaise’a Pascala. Ten wyjątkowo zdolny człowiek połowę ze swego niespełna czterdziestoletniego życia przeżył w cierpieniu wskutek nieuleczalnej choroby. Efektem rozlicznych przemyśleń B. Pascala stała się Modlitwa o dobry użytek z chorób zawarta w Myślach - jednym z jego bardziej znanych dzieł. Autor doświadczający postępującej choroby zwraca się ze swoim cierpieniem do Boga, ufając, że wszelkie trudy, dolegliwości, jak i nieszczęścia spadające na człowieka należą do doskonałego boskiego planu. Ze zrozumieniem godnym podziwu przyjmuje on chorobę. Uważa, że zdrowie dane człowiekowi od Boga jest niedocenionym przez ludzi darem. Według autora Myśli powszechnym niestety jest ignorowanie tak bezcennego stanu. W słowach: „zsyłasz mi obecnie chorobę, aby mnie poprawić"43 Pascal zwraca uwage na wyjątkowe przesłanie związane z doświadczaniem cierpienia. Choroba, w myśl jego słów, jest okazją do zatrzymania się w życiowym pędzie, wraz z możliwością wglądu w samego siebie. Zwraca potomnym uwagę na niebywałe zagubienie duszy ludzkiej, mające swe źródło w przywiązaniu do dóbr doczesnych. Według B. Pascala bogactwa materialne, chlubna reputacja i dobre zdrowie z jednej strony sprzyjają doświadczaniu szczęścia, jednak prymat tych wartości może prowadzić do zaniedbania wartości znacznie ważniejszych. B. Pascal pisał: „albowiem Panie, najcięższa z chorób to ta bezczułość i ta ostateczna niemoc, która duszy mej odjęła wszelkie poczucie jej nędzy" ${ }^{4}$.

Cierpienie jest wobec tego doniosłym sprawdzianem stanu duszy ludzkiej. To właśnie choroba otwiera drzwi duszy, przez które może wejść sam Bóg. Przyjęcie z pokorą cierpienia pozwala zjednoczyć się z cierpiącym Chrystusem, być bezpośrednim świadkiem i uczestnikiem zbawienia poprzez cierpienie, pomaga wyrzec się egoizmu. Chrystus jest dla B. Pascala jedynym pośrednikiem i wybawicielem, jedynym celem życiowych poszukiwań: „Boga tylko żądam i szukam. O Boże, Ciebie jednego proszę i do Ciebie jednego zwracam się, aby otrzymać. Otwórz moje serce Panie, wnijdź w tę oporną fortecę, którą zajęły grzechy"45. Cierpienie niesione przez choroby staje się według Pascala kluczem do owej warowni.

${ }^{42}$ Por. J. Tarnawa, Cierpienie, umieranie, nadzieja, Wydawnictwo WAM, Kraków 2003, s. 104-107.

43 B. Pascal, Myśli oraz Rozprawa o namiętnościach miłości; Rozprawa o kondycji możnych; Modlitwa o dobry użytek chorób, Wydawnictwo PAX, Warszawa 1953, s. 14.

44 Tamże, s. 18.

45 Tamże, s. 16. 
W dziele O naśladowaniu Chrystusa, którego autorstwo przypisuje się Tomaszowi z Kempis - mistykowi żyjącemu na przełomie XV i XVI wieku - można odnaleźć zbliżone stanowisko. Wszelkie doświadczenia zesłane człowiekowi pochodzą od Boga, więc wszelką troskę o siebie należy powierzyć Bogu. Stąd również płynie nauka o możliwości wykorzystania cierpienia do pełniejszego zbliżenia się do Stwórcy ${ }^{46}$.

Jan Paweł II w Salvifici Doloris zwraca uwagę na „wielkość swoistej tajemnicy” zawartej w ludzkim cierpieniu. To właśnie ludzie dotknięci chorobami stają się „drogą Kościoła”, który jest świadkiem cierpienia odkupiającego przewinienia. Aby odnaleźć odpowiedź o przyczyny cierpienia Jan Paweł II nawołuje do odniesienia się do Bożej miłości będącej ostatecznym sensem wszystkiego: „Miłość jest [...] najpełniejszym źródłem odpowiedzi na pytanie o sens cierpienia. Odpowiedzi tej udzielił Bóg człowiekowi w Krzyżu Jezusa Chrystusa"47. Cierpienie jest drogą do odkupienia i bezgranicznego poddania się woli Boga. Chrześcijańska postawa wobec cierpienia mająca za fundament wiarę pomaga niemal zupełnie pojąć brzemię doświadczanych przez ludzi przypadłości.

W religii chrześcijańskiej to Chrystus nadaje cierpieniu sens i nowe znaczenie. W cierpieniu człowiek może upodabniać się do Zbawiciela i jednoczyć z Jego zbawczą męką ${ }^{48}$. Wiara pozwala choremu i cierpiącemu chrześcijaninowi patrzeć z nadzieją i ufnością w przyszłość, gdyż ufa, że nie pozostaje osamotniony, ale jest $\mathrm{z}$ nim Chrystus pomagający mu nieść krzyż cierpienia. Nadto wierzy w uzdrawiającą moc Boga, który doświadczając człowieka cierpieniem pragnie go udoskonalić i ukierunkować na transcendencję ${ }^{49}$. Cierpienie, które jest stale obecne w życiu człowieka, przyjmowane w duchu wiary, staje się źródłem mocy dla cierpiącego. Zwracając się do osób chorych i starszych Jan Paweł II pisze: „Wiara rozjaśnia [...] tajemnicę śmierci i opromienia swym światłem starość, która nie jest już postrzegana i przeżywana jako bierne oczekiwanie na moment unicestwienia, ale jako zapowiedź rychłego już osiągnięcia pełnej dojrzałości" ${ }^{50}$. Przyjmując cierpienie człowiek

${ }^{46}$ Por. Tomasz A Kempis, O naśladowaniu Chrystusa, Instytut Wydawniczy PAX, Warszawa 1984, s. 34, 51-53.

47 Jan Paweł II, List Apostolski Salvifici Doloris do biskupów, kapłanów, rodzin zakonnych i wiernych Kościoła katolickiego o chrześcijańskim sensie ludzkiego cierpienia, wydanie internetowe: http://www.opoka.org.pl/biblioteka/W/WP/jan_pawel_ii/listy/salvifici.html (25.06.2018).

48 Por. Katechizm Kościoła Katolickiego, s. 358 (nr 1505).

${ }^{49}$ Por. W. Wilowski, Metafizyka cierpienia. Od Arystotelesa, poprzez myśl indyjską, do myśli chrześcijańskiej, Wydawnictwo Naukowe Instytutu Filozofii Uniwersytetu im. Adama Mickiewicza, Poznań 2010, s. 199.

${ }^{50}$ Jan Paweł II, List Ojca świętego do moich sióstr i braci - ludzi w podeszłym wieku, wydanie internetowe: https://opoka.org.pl/biblioteka/W/WP/jan_pawel_ii/listy/do_starszych_01101999. html (25.06.2018). 
wierzący łączy je z cierpieniem Chrystusa. Jak pisze Mirosław Brzeziński „tylko wiara człowieka w Jezusa i w zbawczy sens cierpienia pozwala przyjąć je z miłością i nadać mu sens" ${ }^{51}$.

Warto przywołać również poglądy Karla Jaspersa. Droga życiowa niemieckiego filozofa niezupełnie była zgodna z doktrynami religijnymi. Został ochrzczony i bierzmowany w kościele protestanckim, jednak przypisywanie istotnej roli religii w jego życiu byłoby nadużyciem. Już w osiemnastym roku życia zdiagnozowano u Jaspersa chroniczną chorobę, która rzuciła cień na dalsze życie filozofa, odzwierciedlony w jego filozoficznej refleksji ${ }^{52}$. Egzystencjalista ten w swojej koncepcji zwraca uwagę na potrzebę nieustannego określania siebie, swoich postaw, zajmowania stanowiska wobec własnych myśli, działań, stosunku do siebie samego w odwołaniu do podzielanych wartości i norm. Pomocne w poznawaniu siebie są według niego sytuacje graniczne będące poza empirycznym poznaniem. Są one rzeczywistym znakiem ludzkiej egzystencji ${ }^{53}$. Za jedną z sytuacji granicznych Jaspers przyjął cierpienie, m.in. wynikające z doświadczania choroby. Cierpienie rozbudza egzystencję - twierdził. Dopiero w cierpieniu człowiek jest w stanie uruchomić wszelkie możliwe zasoby uśpione dotychczas w jego wnętrzu ${ }^{54}$. Sytuacje graniczne stają się zatem testem i próbą dojrzałości zarówno psychofizycznej, jak i duchowej, ukazują realność egzystencji niematerialnej ${ }^{55}$. Człowiek w obliczu cierpienia zmierza się z dwoma wyborami: możliwością poddania się i rezygnacji, lub też skierowaniu siebie i swojej niedoli ku wyższym ideom: „możliwa egzystencja wznosi się w sytuacji granicznej ku doświadczeniu swej jedności z jej transcendencją w źródle" ${ }^{56}$. Podejmując się tej drugiej postawy, jednostka zostaje skonfrontowana ze swoją nieograniczoną wolnością, przez co doświadczać może pełnego wymiaru własnej egzystencji ${ }^{57}$.

Jasperowska postawa pełni wolności w cierpieniu została ukazana w ekranizacji wspomnień redaktora naczelnego czasopisma ELLE w filmie Motyl i skafander, w którym Jean-Dominique Bauby, sparaliżowany po wylewie i porozumiewający się ze światem wyłącznie poprzez mruganie jedynym sprawnym okiem, mimo początkowej rezygnacji z woli życia wskutek udręki bycia więźniem własnego ciała, odnajduje swoją niezwykłą egzystencjalną

${ }_{51}$ M. Brzeziński, Wiara $w$ doświadczeniu choroby i cierpienia, „Studia nad Rodziną” 2013, nr 1, s. 217.

52 Por. R. Rudziński, Jaspers, Państwowe Wydawnictwo Wiedza Powszechna, Warszawa 1978, s. $10-16$.

53 Tamże, s. 186-242.

54 Tamże, s. 212-216.

55 Por. Kociuba J. Jakość czy sens starości? w: Starość darem, zadaniem i wyzwaniem, red. A. Zych, Wydawnictwo Progres, Sosnowiec-Dąbrowa Górnicza 2014, s. 39-41.

56 R. Rudziński, s. 215.

57 Por. Tamże, s. 215-216. 
wolność w uwięzieniu właśnie. Jego podróże po własnym „wnętrzu” zostały opisane w książce, którą - będąc w niemal zupełnej niemocy - udało mu się przygotować przed śmiercią ${ }^{58}$. Historia ta jest niezwykłym przykładem egzystencjalnej wolności.

Konsekwencje choroby - jak podaje Cornelius van der Poel - mogą wywierać pozytywny wpływ na ludzkie życie i rozwój osobisty. Wskazywane przez tego badacza egzemplifikacje dobroczynnych aspektów cierpienia, to:

- wywołanie i pogłębienie związków międzyludzkich; pacjent przez uznanie własnych ograniczeń doświadcza co oznacza bycie zależnym od innych rodziny, opiekunów, lekarzy i uczy się szacunku do tych osób, natomiast u opiekuna wezwanie do sprawowania opieki może pogłębić zrozumienie znaczenia poczucia wartości;

- udział w procesie pokuty, a przy tym nadanie głównego znaczenia wartościom duchowym - zwrócenie się i oddanie opiece Boga;

- międzyludzka solidarnośćc ${ }^{9}$.

Ryszard Fenigsen zwraca ponadto uwagę na jeszcze inne znaczenie cierpienia; w tym ujęciu jednak istotne dla zdrowej części społeczeństwa, w którym funkcjonują jednostki chore. Według tego autora: „ich egzystencja wzbogaca naszą wizję świata i ludzkości, ukazując, że na różne sposoby można być człowiekiem. Swą wolą życia, przez cierpliwą akceptację swego kalectwa i nieraz bohaterskie jego przezwyciężanie są dla nas wszystkich przykładem i dodają nam odwagi w naszych własnych trudnościach. Ale przede wszystkim spełniają jedną najważniejszą rolę w ludzkiej wspólnocie: budzą w nas to co najlepsze"60.

Choroba wpływa na więzi społeczne. Z jednej strony może być powodem osamotnienia i wykluczenia społecznego, gdy człowiek cierpiący nierzadko zostaje opuszczony nawet przez najbliższych, z drugiej jednak, wzmacnia więzi rodzinne, gdy chory doświadcza silnego wsparcia ze strony rodziny, przyjaciół i znajomych, którzy otaczają go troskliwą opieką oraz okazują mu miłość i przywiązanie. Choroba może być dramatycznym doświadczeniem destabilizującym rodzinę, ale może też ją integrować ${ }^{1}$. Obecność najbliższych jest szczególnie ważna, gdy chory zmagając się z chorobą i cierpieniem doznaje „pokusy pogrążenia się w rozpaczy i jakoby unicestwienia się w niej”62.

${ }_{58}$ M. Pichlak, Motyl i skafander, „Biuletyn EBIB” 2011, nr 6(124), wydanie internetowe: http:// www.ebib.pl/images/stories/numery/124/124_pichlak2.pdf (25.06.2018).

59 Por. C. van der Poel, Dojrzewając przez ból i cierpienie, Wydawnictwo „Jedność”, Kielce 1999, s. 111-116.

${ }^{60}$ R. Fenigsen, Eutanazja: śmierć z wyboru? Wydawnictwo „W drodze”, Poznań 2002, s. 38.

${ }_{61}$ Por. M. Brzeziński, s. 217.

${ }^{62}$ Jan Paweł II, Encyklika Evangelium vitae, s. 126 (nr 67). 
Rodzina stanowi ważne oparcie dla chorego, jeśli towarzyszy mu w chorobie i stara się przynieść mu ulgę w cierpieniu ${ }^{63}$.

W obliczu zbliżającej się śmierci medycyna może jedynie uśmierzyć cierpienia fizyczne osoby umierającej, jednak o wiele istotniejsze jest wsparcie w cierpieniu duchowym. Ważna jest pomoc ze strony rodziny i społeczeństwa. Umożliwia ona zaspokojenie potrzeb chorego, a przede wszystkim łagodzi jego lęki i poczucie osamotnienia. Osoby cierpiące wyrażają potrzebę obecności innych, co świadczy o społecznym wymiarze człowieczeństwa. Cierpienie i umieranie są wydarzeniami, którym trudno sprostać w samotności. Dla umierającego, jak i osób towarzyszących międzyludzka solidarność pomaga w utrzymaniu poczucia własnej godności i sensu swojej egzystencji ${ }^{64}$.

\section{Refleksje końcowe}

Egzystencjalna rola choroby jest uwarunkowana stanowiskiem człowieka wobec cierpienia. Każdy bowiem człowiek indywidualnie i osobiście reaguje na chorobę oraz postrzega jej rolę w swoim życiu. Cierpienia burzą naturalną harmonię w życiu człowieka. Zagrożenia związane z chorobą, zwłaszcza nieuleczalną, implikują egzystencjalny lęk kwestionując integralne bezpieczeństwo danej jednostki ${ }^{65}$. Osoby terminalnie chore wobec lęku przed cierpieniem i nieuchronną śmiercią są gotowe do podejmowania aktywności wcześniej niebranych pod uwagę; poszukiwania antidotum u przedstawicieli medycyny niekonwencjonalnej, poddawania się magicznym zabiegom, wydawania pieniędzy na quasi-uzdrowicieli i ich eksperymentalne preparaty bądź wycofanie się z życia społecznego; izolację, przyjmowanie narkotycznych środków uśmierzających ból, próby odebrania sobie życia. Inną formą radzenia sobie $\mathrm{w}$ chorobach terminalnych jest podejmowanie doniosłych inicjatyw jako element targowania się z Bogiem o zdjęcie cierpienia w zamian za aktywność skierowaną na pomoc innym cierpiącym ${ }^{66}$.

Doświadczanie utraty kontroli nad swoim zdrowiem jest u osób chorych często przyczyną zwrotu ku religii. Wymaga to nierzadko podjęcia wysiłku

${ }^{63}$ Por. M. Kalinowski, Zadania rodziny i służby zdrowia w świecie ludzkiego cierpienia, w: Cierpienie, między sensem a bezsensem. Studium interdyscyplinarne, red. M. Kalinowski, I. Niewiadomska, L. Szot, Wydawnictwo KUL, Wschodnioeuropejski Narodowy Uniwersytet im. Lesi Ukrainki, Lublin-Łuck 2014, s. 57-59; A. Gasiulowa, Osoba cierpiąca w rodzinie, „Zeszyty Naukowe Wyższej Szkoły Pedagogicznej w Bydgoszczy. Studia Pedagogiczne” 1996, nr 32, s. 23-28.

${ }^{64}$ Por. W. Bołoz, Cierpienie duchowe w chorobie terminalnej, „Polska Medycyna Paliatywna” 2004, nr 3(1), s. 63.

65 Tamże, s. 64.

${ }^{66}$ Por. B. Stelcer, Żal po stracie - dynamika adaptacji do nieuniknionych zmian, „Sztuka Leczenia” 2015, nr 3-4, s. 51. 
w poszukiwaniu sensu życia mimo doświadczania ciągłego bólu, frustracji, świadomości śmierci. Bycie religijnym pomaga jednak w pogodzeniu się ze świadomością, że zło, ból, cierpienie i niesprawiedliwość stanowią części składowe ludzkiej egzystencji, a ponadto - poprzez praktyki religijne - daje poczucie niczym nieograniczonej ochrony przed tymi faktami. Jest zarówno podjęciem walki przeciwko pogłębiającej się frustracji i śmierci ${ }^{67}$, jak i poszukiwaniem uzasadnienia dla nieoczekiwanych przemian zachodzących w bio-psycho-społecznym funkcjonowaniu osoby chorej.

Istotną zmienną różnicującą postawy wobec choroby jest wiara w Boga lub jej brak. Z dużym prawdopodobieństwem można założyć, iż dla osób wierzących choroba jest stanem, w którym najczęściej skłaniają się ku refleksji i otwierają się na transcendencję, poszukując pomocy Boga w cierpieniu. W zdecydowanie mniejszym stopniu prawidłowość ta dotyczy wątpiących lub niewierzących. W ich przypadku choroba rzadziej przekonuje do poszukiwania transcendencji, jednak również i oni podczas zmagania się z cierpieniem zaczynają się zastanawiać nad sensem życia, a przy tym dostrzegają i rozumieją znikomość swojego istnienia i jego przemijalność. Doświadczanie tragizmu egzystencjalnej samotności (niektórych z nich) może również skłaniać do szukania oparcia w Bogu ${ }^{68}$.

Z perspektywy socjologicznej, psychicznej i medycznej dostrzega się wyraźną różnicę w doświadczaniu cierpienia u osób wierzących w obecność Boga i jego działanie w zdrowiu i chorobie niż u osób niewierzących ${ }^{69}$. Jednakże zarówno dla wierzących, jak i niewierzących choroba może być przyczyną wprowadzania nierzadko radykalnych zmian w dotychczasowe życie i powodem rekonstrukcji wartości. Cierpienie może być przyczyną negacji Boga lub początkiem duchowego rozwoju człowieka prowadząc do wewnętrznej dojrzałości i pełni człowieczeństwa ${ }^{70}$. Jak wskazuje Dorota Kubacka-Jasiecka: „Poszukiwanie sensu i znaczenia wydarzeń krytycznych jest uważane za stosunkowo powszechnie [...] podejmowaną strategię adaptacyjną zmagania się z sytuacjami krytycznymi, zmierzającą do zrozumienia i oswojenia tego, co się dzieje. Składają się nań wszelkie wysiłki poznawcze na rzecz zrozumienia, nadania znaczenia przebiegowi wydarzeń rzeczywistości wewnętrznej i zewnętrznej. Stanowią one wyraz dążenia do określo-

${ }^{67}$ Por. B. Woźniak, Zaangażowanie religijne a stan zdrowia osób w wieku podeszłym: mechanizmy zależności, wybrane wyniki badań, „Przegląd Socjologiczny” 2012, nr 61(2), s. 230-232.

${ }^{68}$ Por. G. Hurtado, Niewierzacy a poszukiwanie Boga, wydanie internetowe: https://opoka.org. pl/biblioteka/F/FR/or201103-niewierzacy.html (27.06.2018); A. Kaniewska, Ateista o Bogu - rozmowa z filozofem Alainem de Bottonem, wydanie internetowe: https://www.polityka.pl/tygodnikpolityka/ swiat/1525829,1,ateista-o-bogu---rozmowa-z-filozofem-alainem-de-bottonem.read [dostęp: 27.06.2018].

${ }^{69}$ Por. L. Kazimierczak, P. Prüfer, Potrzeba istnienia hospicjum w parafii. Teologiczno-pastoralny przyczynek o cierpieniu, chorobie i starości, w: Cierpienie: dylematy egzystencjalne, red. E. Bartkowiak, P. Prüfer, Zielona Góra 2009, s. 39-50.

70 Por. J. Tarnawa, Cierpienie, umieranie, nadzieja, s. 101-107. 
ności, pewności i bezpieczeństwa dzięki odniesieniu ich do konceptualizacji świata przez jednostkę i swojej w nim roli, a także posiadanych przekonań, światopoglądu i moralnych wartości"71.

W zakończeniu warto przytoczyć słowa nieżyjącego już księdza Jana Kaczkowskiego: „Nie użalajcie się nade mną, że taki młody i biedny. Nie jestem aż taki biedny, w jakimś sensie jestem szczęśliwy, że ta choroba przyszła, bo ona mnie wyzwoliła z lęku. Miałem mnóstwo kompleksów, bałem się rzeczy głupich, irracjonalnych, byłem pyszny. [...] Dziękuję ci, mój raku, że wyzwoliłeś mnie $z$ wielu strachów"72. W obliczu nieuchronnego końca piękno, dobrobyt, pogoń za szczęściem i samostanowieniem - a zwłaszcza lęk przed ich utratą bądź brakiem możliwości osiągnięcia - przestają mieć jakiekolwiek znaczenie. Wiara w Nieskończoność wydaje się tu jednak być czynnikiem zasadniczym.

Trwanie w przewlekłej chorobie pozwala jednostce na przyjęcie pokornej postawy wobec doświadczanego cierpienia, kruchości istnienia, a jednocześnie na zwrócenie uwagi na sprawy dotychczas zaniedbywane. Rozwaga i wiara natomiast pozwalają te sprawy oddzielić. Wśród osób zmagających się z chorobą alkoholową i pragnących wyzwolić się ze swoich słabości i uzależnienia popularnością cieszy się Modlitwa o pogodę ducha:

„Boże, użycz mi pogody ducha, abym godził się z tym czego nie mogę zmienić, odwagi, abym zmieniał to co mogę zmienić, i mądrości, abym potrafi odróżnić jedno od drugiego"73.

W swojej prostocie wymowy stanowi ona we współczesnym świecie jedną z piękniejszych modlitw o dobry użytek z doświadczania przewlekłej, nieuleczalnej przypadłości.

\section{Bibliografia}

Bajer D., Egzystencjalizm jako filozofia podmiotu, „IDEA - Studia nad strukturą i rozwojem pojęć filozoficznych" 2011, nr 23, s. 115-134.

Bartoszek A., Moralne aspekty "jakości życia” w opiece paliatywnej, „Śląskie Studia Historyczno-Teologiczne" 2002, nr 35, s. 309-330.

71 D. Kubacka-Jasiecka, Kryzysy zdrowia a możliwości zmagania się z cierpieniem choroby somatycznej, „Sztuka Leczenia” 2010, 20(1-2), s. 32.

${ }^{72}$ J. Kaczkowski, Grunt pod nogami, Kraków 2016, s. 20-21.

${ }^{73}$ I. Kaczmarczyk, Terapeutyczne oddziaływania Wspólnoty Anonimowych Alkoholików, w: Psychoterapia Pogranicza, red. L. Grzesiuk, H. Suszek, Wydawnictwo Eneteia, Warszawa 2012, s. 523. 
Bołoz W., Cierpienie duchowe w chorobie terminalnej, „Polska Medycyna Paliatywna” 2004, nr 3(1), s. 57-65.

Brzeziński M., Wiara w doświadczeniu choroby i cierpienia , „Studia nad Rodziną” 2013, nr 1, s. 217-233.

Cattaneo P. Dlaczego Bóg dopuszcza cierpienie?, Kraków 2008.

Czarnecki Z.J., Słownik najważniejszych terminów filozoficznych, w: Świat, człowiek i wartości. Wybór tekstów filozoficznych dla szkół średnich, red. J. Cabaj, Z.J. Czarnecki, H. Jakuszko, J. Zdybel, s. 349-360.

Drożdż B., Alienacja w świetle egzystencjalizmu, „Perspectiva. Legnickie Studia Teologiczno-Historyczne" 2006, nr 5(1), s. 52-61.

Duda K., Fenomenologia cierpienia. Zarys problematyki, w: Ból i cierpienie, red. G. Makiełło-Jarża, Kraków 2011, s. 9-17.

Fenigsen R., Eutanazja: śmierć z wyboru?, Poznań 2002.

Gasiulowa A., Osoba cierpiq̨ca w rodzinie, „Zeszyty Naukowe Wyższej Szkoły Pedagogicznej w Bydgoszczy. Studia Pedagogiczne" 1996, nr 32, s. 23-28.

Hurtado G., Niewierzacy a poszukiwanie Boga, wydanie internetowe: https://opoka.org.pl/biblioteka/F/FR/or201103-niewierzacy.html [dostęp: 27.06.2018].

Jan Paweł II, Encyklika Evangelium vitae, Poznań 1995.

Jan Paweł II, List Apostolski Salvifici Doloris do biskupów, kapłanów, rodzin zakonnych i wiernych Kościoła katolickiego o chrześcijańskim sensie ludzkiego cierpienia, wydanie internetowe: http:// www.opoka.org.pl/biblioteka/W/WP/jan_pawel_ii/listy/salvifici.html [dostęp: 25.06.2018].

Jan Paweł II, List Ojca świętego do moich sióstr i braci - ludzi w podeszłym wieku, wydanie internetowe: https://opoka.org.pl/biblioteka/W/WP/jan_pawel_ii/listy/do_starszych_01101999.html [dostęp: 25.06.2018].

Kaczkowski J., Grunt pod nogami, Kraków 2016.

Kaczmarczyk I., Terapeutyczne oddziaływania Wspólnoty Anonimowych Alkoholików, w: Psychoterapia Pogranicza, red. L. Grzesiuk, H. Suszek, Warszawa 2012, s. 519-544.

Kalinowski M., Zadania rodziny i służby zdrowia w świecie ludzkiego cierpienia, w: Cierpienie, między sensem a bezsensem. Studium interdyscyplinarne, red. M. Kalinowski, I. Niewiadomska, L. Szot, Lublin 2014, s. 53-64.

Kaniewska A., Ateista o Bogu - rozmowa z filozofem Alainem de Bottonem, wydanie internetowe: https://www.polityka.pl/tygodnikpolityka/swiat/1525829,1,ateista-o-bogu---rozmowa-zfilozofem-alainem-de-bottonem.read [dostęp: 27.06.2018].

Katechizm Kościoła Katolickiego, Poznań 1994.

Kazimierczak L., Prüfer P., Potrzeba istnienia hospicjum w parafii. Teologiczno-pastoralny przyczynek o cierpieniu, chorobie i starości, w: Cierpienie: dylematy egzystencjalne, red. E. Bartkowiak, P. Prüfer, Zielona Góra 2009, s. 39-50.

Kociuba J., Jakość czy sens starości? w: Starość darem, zadaniem i wyzwaniem, red. A. Zych, Sosnowiec-Dąbrowa Górnicza 2014, s. 33-48.

Kubacka-Jasiecka D., Kryzysy zdrowia a możliwości zmagania się z cierpieniem choroby somatycznej, "Sztuka Leczenia" 2010, 20(1-2), s. 21-41.

Längle A., Analiza egzystencjalna - poszukiwanie zgody na życie, „Psychoterapia” 2003, nr 2(125), s. 33-46.

Ledwoń I.S., Teologiczna interpretacja sensu cierpienia, w: Cierpienie, między sensem a bezsensem. Studium interdyscyplinarne, red. M. Kalinowski, I. Niewiadomska, L. Szot, Lublin-Łuck 2014, s. 7-19.

Lewicki M., O Jeana Paula Sartre'a projekcie człowieka w sytuacji, ,Zeszyty Naukowe Towarzystwa Doktorantów Uniwersytetu Jagiellońskiego. Nauki Humanistyczne" 2011, nr 3(2), s. 45-56.

Markiewicz B., Od Nietzschego do filozofii współczesnej. Wybór tekstów, Warszawa 1999.

Monge M.Á., Zdrowie, ból ichoroba, w: Etyka w medycynie. Ujęcie interdyscyplinarne, red. M.Á. Monge, Warszawa 2012, s. 183-207.

Mordka A., Transcendencja i sposoby jej poszukiwania w filozofii Karla Jaspersa, "Nowa Krytyka” 1996, nr 7, s. 187-206. 
Mrzygłód P., Etyczno-moralne postawy wobec cierpienia, nieuleczalnej choroby i śmierci człowiekaw świetle ustaleń antropologii filozoficznej, "Studia Teologiczne - Białystok - Drohiczyn - Łomża” 2016, nr 34(2), s. 61-92.

Olczyk A., Posłannictwo Kościoła wobec chorych, „Studia Gdańskie” 2014, nr 35, s. 77-92.

Pascal B., Myśli oraz Rozprawa o namiętnościach miłości; Rozprawa o kondycji możnych; Modlitwa o dobry użytek chorób, Warszawa 1953.

Pichlak M., Motyl i skafander, „Biuletyn EBIB” 2011, nr 6(124), wydanie internetowe: http://www. ebib.pl/images/stories/numery/124/124_pichlak2.pdf [dostęp: 25.06.2018].

Popkin R.H., Stroll A., Filozofia, Poznań 1994.

Przygoda W., Teologia cierpienia i choroby, „Śląskie Studia Historyczno-Teologiczne” 2000, nr 33, s. 257-266.

Rudziński R., Jaspers, Warszawa 1978.

Sartre J.-P., Egzystencjalizm jest humanizmem, w: Materializm historyczny. Etyka, red. A. Ochocki, S. Sarnowski, Warszawa 1969, s. 118-126.

Scheler M., Cierpienie, śmierć, dalsze życie, Warszawa 1994.

Scruton R., Filozofia kontynentalna od Fichtego do Sartrea, w: Oksfordzka ilustrowana historia filozofii, red. A. Kenny, Poznań 2001, s. 225-274.

Siudem I., Konsekwencje represji cierpienia, w: Cierpienie, między sensem a bezsensem. Studium interdyscyplinarne, red. M. Kalinowski, I. Niewiadomska, L. Szot, Lublin-Łuck 2014, s. 169-187.

Solomon R.C., Higgins K.M., Krótka historia filozofii, Warszawa 1997.

Sontag S., Choroba jako metafora. AIDS i jego metafory, Kraków 2016.

Stelcer B., Żal po stracie - dynamika adaptacji do nieuniknionych zmian, "Sztuka Leczenia” 2015, nr 3-4, s. 47-56.

Tarnawa J. Cierpienie, umieranie, nadzieja, Kraków 2003.

Tatarkiewicz W., Historia filozofii, t. 3: Filozofia XIX wieku i współczesna, Warszawa 1981.

Tomasz A Kempis, O naśladowaniu Chrystusa, Warszawa 1984.

Van der Poel C., Dojrzewajac przez ból i cierpienie, Kielce 1999.

Wilowski W., Metafizyka cierpienia. Od Arystotelesa, poprzez myśl indyjska, do myśli chrześcijańskiej, Poznań 2010.

Woźniak B., Zaangażowanie religijne a stan zdrowia osób w wieku podeszłym: mechanizmy zależności, wybrane wyniki badań, „Przegląd Socjologiczny” 2012, nr 61(2), s. 207-242.

Żelazny M., Pojęcie znaku egzystencji i szyfru transcendencji w filozofii Jaspersa (próba komentarza), "Humanistyka i Przyrodoznawstwo" 2011, nr 17, s. 51-60.

Žuromskaitè B. Choroba: kara czy wyzwolenie? Stosunek do choroby w epoce nowożytnej, wydanie internetowe: http://www.racjonalista.pl/kk.php/s,4771 [dostęp: 25.06.2018].

\section{Streszczenie:}

Współczesna kultura masowa charakteryzuje się promowaniem kultu ciała, wygody, doznawania przyjemności, życia pełnego ekscytujących przygód i ciągle pobudzaną zachętą posiadania kolejnych dóbr uznawanych za niezbędne i dające szczęście. Popularność zyskuje eudajmonizm i sybarytyzm. Wartości hedonistyczne coraz częściej zajmują naczelne miejsce w środkach masowego przekazu, natomiast coraz mniej mówi się o chorobie i cierpieniu, które przez współczesnego człowieka bywają postrzegane najczęściej jako nieracjonalne zło kolidujące z promowanym utopijnym i hedonistycznym wizerunkiem ludzkiej egzystencji.

$\mathrm{W}$ artykule podjęto próbę przedstawienia roli choroby, zwłaszcza wpływu bólu, cierpienia i dysfunkcji ludzkiego ciała na egzystencję człowieka oraz jego stosunek do transcendencji. W odwołaniu do przedstawicieli egzystencjalizmu ateistycznego i teistycznego ukazano zróżnicowane ujęcia cierpienia. Opisano znaczenie choroby w życiu człowieka oraz wskazano przyczyny dewaluacji 
wartości związanych z jej doświadczaniem. Ponadto, na podstawie analizy treści publikacji autorów podejmujących kwestie cierpienia, podano przykłady określające chorobę jako fundament istotnych egzystencjalnych przemian, potwierdzając istotną rolę cierpienia, jako możliwości rozwoju duchowego oraz integracji $z$ transcendencją. Przedstawiono również różnice w postawach wobec choroby i cierpienia związane z wyznawaniem wiary w Boga lub jej brakiem, a także powiązania w podejmowanych działaniach obserwowane zarówno u osób wierzących jak i ateistów w reorganizacji świata wartości w obliczu doświadczanego kryzysu. W odwołaniu do przykładów z literatury zaprezentowano stanowiska wobec nadchodzącej i nieuchronnej śmierci przyjęte przez osoby cierpiące, przedstawiono także rolę rodziny i otoczenia społecznego we wsparciu osób terminalnie chorych w godnym zakończeniu życia. Zwrócono uwagę na rolę duchowego wsparcia w doznawanych cierpieniach w trakcie świadomego żegnania się ze światem żywych, znacznie istotniejszą - zdaniem autorów artykułu - niż jedynie farmaceutyczne uśmierzanie cierpień fizycznych.

Słowa kluczowe: choroba, cierpienie, śmierć, egzystencja

\section{The Existential Role of Illness}

\section{Summary}

Contemporary mass culture is characterized by the promotion of body worship, comfort, pleasure, a life full of exciting adventures and a constantly stimulated encouragement to have more of the goods considered essential for happiness. Eudemonism and sybaritism are becoming more popular. Hedonistic values are increasingly being portrayed in the mass media, and less and less talk about illness and suffering, which by modern man are often perceived as irrational evil colliding with the promoted utopian and hedonistic image of human existence.

The article attempts to present the role of the disease, especially the impact of pain, suffering and dysfunction of the human body on human existence and its relationship to transcendence. Differentiated views on suffering were discussed based on the works by representatives of atheistic and theistic existentialism. The significance of illness in human life was described and the reasons for the depreciation of the values related to this experience were pointed out. In addition, based on the analysis of the publications by the authors addressing the issue of suffering, the examples depicting illness as the foundation for significant existential changes are presented, which confirms the essential role of suffering as opportunity for spiritual development and integration with transcendence. Differences in attitudes towards illness and suffering related to the belief in or lack of God, as well as connections in the actions taken, observed both in believers and atheists in the reorganization of the world of values in the face of the experienced crisis were also presented. In reference to examples from the literature, positions regarding the approaching death adopted by the suffering people were presented, as well as the role of the family and social environment in supporting terminally ill people in a dignified end of life. Attention was paid to the role of spiritual support in the suffering experienced during a conscious goodbye to life, which is much more important - according to the authors of the article - than only the pharmaceutical alleviation of physical suffering.

Keywords: illness, suffering, death, existence 